

\title{
Anatomy of a techno-creative community: the role of places and events in the emergence of videomapping in Nantes
}

Etienne Capron, Dominique Sagot-Duvauroux, Raphaël Suire

\section{To cite this version:}

Etienne Capron, Dominique Sagot-Duvauroux, Raphaël Suire. Anatomy of a techno-creative community: the role of places and events in the emergence of videomapping in Nantes. 2020. hal-02617101v3

\section{HAL Id: hal-02617101 https://univ-angers.hal.science/hal-02617101v3}

Preprint submitted on 26 Nov 2020

HAL is a multi-disciplinary open access archive for the deposit and dissemination of scientific research documents, whether they are published or not. The documents may come from teaching and research institutions in France or abroad, or from public or private research centers.
L'archive ouverte pluridisciplinaire HAL, est destinée au dépôt et à la diffusion de documents scientifiques de niveau recherche, publiés ou non, émanant des établissements d'enseignement et de recherche français ou étrangers, des laboratoires publics ou privés. 


\title{
Anatomy of a techno-creative community - the role of places and events in the emergence of videomapping in Nantes
}

\author{
Etienne Capron (GRANEM, University of Angers)* \\ Dominique Sagot-Duvauroux (GRANEM, University of Angers) \\ Raphaël Suire (LEMNA, University of Nantes)
}

\section{May 2020}

Word count: 8710 words (including bibliography)

\begin{abstract}
This article aims to study the role of places and events in the structuring of a community of innovation whose practice is at the crossroads of art and tech - videomapping. Based on an exploratory case study, we observe the relationships between the different actors who form subgroups, sharing a common interest in a techno-creative practice - but whose collective innovation dynamic is only in its beginnings. We also document the usage of places and events in their intermediation role for these subgroups. This reveals preferential circulations - patterns of moves among a set of focal locations in the city for a community - and the crucial role of these locations in creative communities emergence.
\end{abstract}

Keywords: techno-creative innovation; places; knowledge; network analysis.

JEL Code : D85, O32, R11, Z10

\section{Introduction}

The past two decades have seen a multiplication of regional policies inspired by the creative class (Florida, 2002) and creative cities (Landry and Bianchini, 1995), based on cultural and creative industries support (Boix et al, 2016). Related economic sectors (mainly art, media, digital and technology, video games, etc.) have become a major source of employment, yet also produce many external effects for other sectors (Sedita et al, 2016). At the same time, they deeply transform territories in three interwoven dimensions: urban transformation through embellishment of deprived areas; demography of population through influx of creative and knowledge workers, and economic transformation through convergence toward knowledge intensive economic sectors (Scott, 2014). However, the spatial coexistence of (un-)related creative sectors does bring new opportunities for regional cross-specialization (Janssen and Frenken, 2019; Frenken et al, 2007), and the co-location of different activities could open up a wider, more sustainable range of anchored possibilities for regional development.

\footnotetext{
${ }^{*}$ : corresponding author. Email adress : etienne.capron@univ-angers.fr
} 
Few studies have documented how some related sectors overlap and produce novelties at their respective knowledge borders, even though there is strong interest in this (Content and Frenken, 2016). Furthermore, empirical papers reveal valuable potential in the food industry (Davids and Frenken, 2015) and in offshore gas and wind energy (Ingstrup and Menzel, 2019) - though very little is known about how Cultural and Creative Industries (CCI) cross over; contexts in which STEM (Sciences, Technologies, Engineering, Mathematics) and artistic activities are co-located are rarely studied. Rodriguez-Pose and Lee (2020) provided insights at city level, showing that cities in which both types of activities are present are particularly innovative. The cumulative effects of co-location and possible combinations of knowledge need to be studied at a micro level.

However, innovations are increasingly based on both symbolic and synthetic knowledge bases (Asheim and Gertler, 2006) such as video games (Grandadam et al., 2013) or web design (Christopherson, 2004). Moreover, studies are mostly conducted at macro or organizational levels (international, national, regional). This contribution aims to fill those gaps, firstly by specifying the concept of 'techno-creative' activities: those at the knowledge frontier of arts and digital technologies, qualified as STEAM in the Rodriguez-Pose and Lee approach (op.cit), and secondly by pointing out the crucial roles played by places and events in the emergence of these novelties, based on a localized innovation community (Sarazin et al., 2017). Our goal is to specify the roles played by places, events, and individuals in the emergence of a localized techno-creative activity; these could serve as an interface for knowledge transfer and, as such, a specific asset to creative entrepreneurs (Janssen and Frenken, op.cit).

This paper is based on an exploratory case study (Mills et al., 2010) of the videomapping community in Nantes (France) as an example of a localized, emergent techno-creative activity. This innovation combines symbolic and synthetic knowledge and is associated with several types of creatives (architects, video-jockeys (VJs), video artists). Results identify preferential circulation of community members, which can be defined as the pattern of moves made by a community between a set of focal locations in the city. Subgroups within the community have specific focal points, though few common places with the other subgroups. This analysis shows that the innovation community frequents a multiplicity of places and events (in terms of size, orientation, etc.), and that access to the resources provided by these places and events is not open to all in the same way. Once emerging activities have been detected by public institutions, a policy of material and economic support to these could benefit their structuring (provision of workspace, logistical assistance, financing of long-term residencies, etc.). 
The paper is organized as follows: the first part frames the theoretical approach, from which we derive our research questions. The second part is dedicated to methodology, building on semi-directive interviews. The collected data also allows us to conduct network analysis. The third part is devoted to the results, which are discussed in the fourth part, and our conclusion highlights policy implication.

\section{Theoretical background}

Research on the knowledge-based economy that is focused on processes, from creation to the diffusion and use of knowledge, has introduced the notion of knowledge bases and its networks (Balland et al, 2013) in order to specify how innovation processes operate. Within this framework, each activity is based on a knowledge base, according to the industrial sector it belongs to, tacit and codified knowledge used, and skills required. Both Asheim and Gertler, op.cit, and Asheim and Hansen (2009) describe three types of knowledge base: analytical, which is more associated with science-based industries (fundamental research, biotechnology, nanotechnology, etc.) and involves a rational, deductive thinking approach that leads to the creation of highly codified scientific knowledge; symbolic, which is related to CCI and art because it refers to the creation of knowledge of high aesthetic value, embedded in cultural systems of interpretation and having a strong tacit dimension, and synthetic, which is based on combining existing knowledge, and can be found in industries in which the application of solutions to problems is central (e.g. engineering). Depending of the type of activity, there is either only one knowledge base, or one is dominant - and this affects how new knowledge is integrated and created. As pointed out by Rodriguez-Pose and Lee (op.cit), the amalgamation of activities belonging to both the STEM (based on synthetic and/or analytical knowledge) and creative/art sectors could spur innovation at city level. The coexistence of these knowledge bases could produce an ecosystem favorable to the emergence of STEAM innovations (Rodriguez-Pose and Lee, op.cit) and smart diversification. There is a lack of empirical studies on how these knowledge bases overlap at the micro level. We use the term techno-creative activities to fill this gap, by which we mean those combining varying degrees of synthetic and symbolic knowledge to produce innovation, and we focus on the socio-spatial processes that underlie their localized emergence. 
While some knowledge is indeed produced by companies and formal organizations (Balland et al, 2020), not all of it is created by them. Indeed, a plurality of actors having an interest in a particular field participate in the creation of knowledge. Scholars define these as communities - a set of individuals who regularly and voluntarily exchange information about a common interest or shared goal within a knowledge field (Amin and Cohendet, 2004). Though these autonomous, informal collectives are not necessarily oriented around market production, they first and foremost share interests, opinions and practices about whatever it is that brings them together. The role of communities in the processes of collective creation is important, because the diverse interactions between members allow the transfer (formal and/or informal) of knowledge specific to each (Bathelt and Cohendet, 2014). This broad definition can be refined by distinguishing between two different types of communities: Communities of Practice $(\mathrm{CoP})$ are centered on the sharing of best practices within a specific knowledge field (Lave and Wenger, 1991). Since they share the same existing practice, members of these communities also share a common interest in a problem or subject. Interacting with others is one way of sharing experiences, tools and best practices, to improve knowledge. Epistemic Communities (EC) are focused on the creation, codification and dissemination of new knowledge (Haas, 1992; Cowan et al., 2000). EC members compare and contrast their diverse knowledge sets, to create or update new knowledge and develop a framework with which to interpret it. ECs can either operate in existing fields or initiate new ones, which are identifiable by actors outside of the community (Capdevila et al., 2018). The boundaries of these communities are loose, evolving over time as members come and go, becoming more or less involved. In emerging fields, practices are mostly experimenting and prototyping, and since bricolage is a dominant means of identifying the adjacent possible, knowledge cannot be not fully codified (Suire, 2019). Members of CoPs and ECs can therefore spill over into a community, collectively producing something new by combining knowledge, adjusting or initiating practices, developing an interpretative framework, and actively disseminating knowledge (Capdevila et al., ibid). This is what we call an innovation community (Sarazin et al., op.cit).

\section{Proximities dynamic}

If we consider innovation to be a localized product of the combination of knowledge and skills, then we need to understand the dynamics that are driving this process. The interplay of various proximities is an interesting starting point (Rallet and Torre, 2004; Boschma, 2005). All proximities are relative, and their articulation can either spur or hinder exchanges between actors of innovation, i.e. communities of innovation. The type of proximity that matters most 
is also sensitive to the stage or maturity of innovation (Davids and Frenken, 2018). In addition to geographical proximity, which describes both the Euclidean and relative distance between two actors, Boschma identifies four other forms of proximity whose alignment and activation can play a powerful role in collective innovation processes. The first of these is social proximity, defined by the embedding of social relations, i.e. belonging to the same social realm (Granovetter, 1985). The structure and composition of an actor's social space is important; too much homogeneity could limit access to new ideas or opportunities, whereas ties that are too weak (or even non-existent) could limit confidence - and thus exchanges of tacit knowledge. The second form is cognitive proximity, which illustrates the degree of relatedness of actors' knowledge, which can be similar and/or complementary (Boschma, 2017). The commensurability of knowledge is important for mutual understanding (Punstein and Glücker, 2020), and an optimal cognitive distance seems crucial to the promotion of innovation (Nooteboom et al., 2007). The third form is organizational proximity, which refers to belonging to an organizational arrangement regulated by norms and coordination mechanisms, whether formal or informal (e.g. an art collective). This defines actors' degree of autonomy as well as their potential for interacting with others. The fourth form is institutional proximity, defined as the capacity of actors to adopt behaviors in line with the formal rules, common procedures and established practices, or informal values, ways of doing, or ideals (Emin and Sagot-Duvauroux, 2016). In this way, a group develops a collective identity. Where actors are strongly interconnected and interact frequently, shared values and understandings emerge (Jones et al., 1997). Relational (non-geographic) proximity dynamics are governed by two logics (Rallet and Torre, op.cit): the logic of belonging (as members of a single organization, actors interact, and their exchanges are facilitated by their shared formal and informal rules) and the logic of similarity (actors share a system of representations and knowledge, and this similarity facilitates exchange). Proximities, then, allow us to see potential areas of overlap, the interstices in which communities of innovation may form. If they are to facilitate knowledge transfer, innovation communities need relational proximities. But even in a context in which local actors share a single, abiding, geographical space, new combinations involving both synthetic and symbolic knowledge are not guaranteed. Since proximities must be both articulated and activated, we need a more precise investigation of territorial configurations, since these could play a vital role in the emergence and development of communities. 
If we consider actors located in the same territory to be potentially proximate, yet no collective innovation dynamics emerge because they don't share social networks, knowledge or representation frameworks, then we should analyze the endogenous elements of this territory that are capable of promoting crossovers (whether directly or indirectly). The first element is place: an abiding location in which individuals can socialize and share information, and in which social and cognitive flows densify (Rantisi and Leslie, 2010). Following the notion of third-places (Oldenburg, 1989), these offer a favorable context for social interactions, knowledge exchanges, and co-creation. A wide variety of places can play this role, whether for production or diffusion, niche- or mainstream- oriented (Kloosterman, 2014) cafés, restaurants, artist-run spaces, fab-labs, etc. The third-place function is created by the community in making it its focal point, and these places can play a crucial role in the process of creation and/or diffusion of innovations (Kloosterman and Brandellero, 2016). More precisely, the main function of these places can differ from one location to another: creation/production, social interaction, exploitation of knowledge, etc. (Suire and Vicente, 2015; Gibson, 2005). We also assume that places may be more or less open to exploitation (depending on whether they are institutionalized and highly visible, requiring more accomplished productions for a wider audience) or exploration, according the actors more freedom (Suire, 2019).

The second element is event: whether regular or not, events act as temporary clusters (Maskell et al., 2006; Torre, 2008), gathering actors from different territories for a short period of time. By allowing face-to-face encounters, events offer an opportunity to create new social relations (Storper and Venables, 2004). Where they have a worldwide audience, these favor global pipelines, and events provide communities with access to new trends, knowledge, and peer reviews, building local buzz (Bathelt et al., 2004; Rantisi, 2014; Lavanga, 2018). Another crucial characteristic is the field-configuration role an event can have (Meyer et al., 2005; Schüßler et al., 2015). Being both the output of a field and an input to that same field, events can be crucial to the local configuration of a community.

Several contributions also emphasis the crucial role played by social networks in the creation and diffusion of creative productions (Burt, 2004; Perry-Smith, 2006; Uzzi and Spiro, 2005; Cattani and Ferriani, 2008). The structural position of brokers, for example, has been studied in contexts of emergence in artistic fields, highlighting the crucial factor of accessing influential actors and bridging different social worlds and views (Sgourev, 2015; Lingo and O'Mahony, 2010). Brokers can be identified by their position within the network, their activities, and their motivation (Foster and Ocejo, 2013). Following Gould and Fernandez (1989), brokers are defined as individuals who connect previously unconnected alters, whether 
or not these people belong to a single organization or field. Brokers could be important as they serve as 'bridges' between different part of a social realm, thus transforming the dynamics of proximity between actors. On a more structural level, being integrated into the mainstream provides easy access to material and financial resources, as well as peer recognition. Conversely, being located in a peripheral position makes access to these resources more difficult, though because it offers freedom from institutional and peer pressure, it also provides opportunities to create radical new ideas (Grabher, 2018). In this respect, it also seems necessary to: study which actors are disconnected (Philipps, 2011), explain why they are disconnected (whether this disconnection is intentional or not), and find out how to promote the connection of actors - since this could potentially lead to fresh cross-fertilization of knowledge.

The literature shows strong potential for innovation at the intersection of synthetic and symbolic knowledge bases, and the context of STEAM sector co-location also offers opportunities for innovation and new combinations. Actors from different communities would thus share geographical proximity - but how can these communities meet and foster innovation at the intersection? Through their practices, some communities illustrate potential for crossover. The aim of this paper is to understand how a community of innovation emerges at the intersection of art and technology. Of the various forms of crossover available, we have chosen to study 'mappers' in Nantes. Actors have a shared interest for videomapping, but come from diverse backgrounds; they do not share the same values, knowledge, or social realm. There is therefore a need to build or activate relational proximities through places and events, as these can provide favorable contexts for face-to-face interactions, access to material resources, and opportunities to disseminate creations (Rantisi and Leslie, op.cit; Hauge and Hracs, 2010). Brokers - who bring together parts of the network that are disconnected from social networks - could also play a crucial role in terms of interaction between different knowledge frameworks, or access to new opportunities. We have supposed (1) that places, events and brokers can both reduce social distance and promote exploration at the frontier of artistic and technological activities. However, (2) the heterogeneity of actors, their values and their approaches to practice can be obstacles to the constitution of an innovation community. We rely on an empirical study to determine their role in structuring a community of mappers within an ecosystem that combines technological and artistic activities.

\section{Methodology and data}




\section{Field and object of the study}

Since we were observing a social phenomenon in situ, we chose to adopt a qualitative research design based on an explorative case study, which allowed us to focus on less-studied phenomenon (Mills et al., op.cit). As our field for this study, we chose Nantes - a city located in western France which, over the past 30 years, has developed a strategy of territorial and economic development based on cultural events (Ambrosino et al., 2016)). More recently, with the creation of a dedicated cluster (Schieb-Bienfait et al., 2017), the city has focused on attracting the CCI sectors. Nantes was also named European Capital of Innovation in 2019, in recognition of its whole strategy of supporting innovative activities. These two trajectories have recently crossed one another, providing a context that fits the goal of our study ${ }^{1}$. In addition, certain places, and events initiated by the city, are actively seeking to foster crossovers between arts and technology, underlining the desire to develop activities at the intersection of these sectors.

Rather than studying several techno-creative activities, we decided to focus on a single activity, to deepen the analysis. After two preliminary interviews we chose videomapping - a practice we define as projections of still or moving images onto volumes, using the appropriate software and technology - that is, a combination of symbolic and synthetic knowledge. Videomapping actors (mappers) do create content for projection, but also manage the echnological side of that projection. We have assumed that people involved in this practice are capable of initiating innovation, whether radical (e.g. new aesthetics or new technologies) or incremental (e.g. new content). Nevertheless, these people are not necessarily intermediaries between a tech community and an artist community. Rather, they are on the edge of the two knowledge fields, using a greater or lesser degree of synthetic and/or symbolic knowledge. We used this example to explore the roles played by places, events, and people, in articulated proximities, that lead to the emergence of a videomapping innovative community.

\section{Primary and secondary data}

Data collection was conducted via semi-directed interviews with two different categories of actors. First, mappers: those who create and manage content. We interviewed 17 individuals who constitute the core of our sample; some of these people have gathered into collectives. Second, actors having some interest in videomapping, but whose reasons for participating in the community lie elsewhere: event organization, position in a cultural venue,

\footnotetext{
${ }^{1}$ According to the economic development agency Nantes Metropole Entreprises, the city has around 90,000 jobs in the cultural and creative industries and 23,300 jobs in digital technologies and services.
} 
etc. These five individuals provided us with different, though complementary data about this practice in the local context. The sample was constituted using a snowball methodology, as we wanted to identify as many members of the community as possible. However, our sample is not exhaustive. Some mappers could have been overlooked because of being isolated, or invisible to the people we met, and in addition, we were unable to meet every actor we identified, for material reasons (they were not in the area, or unavailable during the study period). The interviews focused on two themes: the functioning of the practice (what tools and processes are used, with whom they collaborate, what their experiences are, how they learned, etc.), and the social, spatial and cognitive resources they mobilize (what places and events they attend and why they do so, who they know as mappers, etc.). We also asked interviewees to hierarchize places, events and people as main resources for meeting other members, nurturing their inspiration, learning, creating and experimenting, and to share their creations. In addition to this primary data collection, we used secondary data sources (websites, Facebook pages) to verify and supplement data obtained through interviews. This was important, since the period during which we conducted the interviews spans 7 months (September 2019 to March 2020). During this time, new creations were presented, new relations were formed, and it integration of these data into our work seemed to be of interest. In total, although we conducted 17 interviews, we identified 40 individuals and collectives, although it was not possible to meet everyone. The data also includes 38 places and 12 events cited by interviewees as resources for their practice, and/or locations they regularly attend.

\section{Network analysis}

In addition to analyzing interview content, the data we obtained allows network analysis. We chose to divide our analysis into three distinct types of networks: one devoted to interpersonal relations (social network), another to relations between individuals and places (bi-partite network), and the last to relations between individuals and events (bi-partite network). In each case, we identify market relationships - that is, when a contract is made regarding the creation, production or diffusion of videomapping content (i.e. the customer-supplier relationship), and non-market relationships (which can take the form of friendship, exchange of knowledge, ideas or advice, recommendations, co-creation or collaboration, lending of materials, etc). For analytical reasons, we have separated the types of relationships each time, but they are embedded (Granovetter, op.cit) and may overlap where two actors have both a market and non-market relationship, since the one may be the consequence of the other. In total, we come up with six non-directed networks, which we 
analyze separately and compare on the basis of their structural properties. Following Uzzi and Spiro (op.cit), we consider that a tie links two places or two events if an individual attends both places (or events). On the basis of attendance data for the locations, gathered through interviews, we obtain one network made up of places, and another made up of events. This is what we call preferential circulation: the pattern of moves made by a given individual or group and observed between a set of places. It reflects the choices, habits, and selection of multiple specific resources (social, economic, cognitive and material). We analyze networks separately, in the same way as social networks.

Various structural analyses of the network were conducted ${ }^{2}$, starting with degree centrality (the number of links a node has), which tells us how central a node is in a network, based on whether it has a low or high number of links. We also measured betweenness centrality, which describes the number of times a node is on the shortest path connecting a pair of nodes in the network. This allowed us to identify intermediaries (such as brokers) within the social network, as well as intermediary places and events in the other two networks. Lastly, we used degree correlation, which reflects the assortativity of nodes: the idea that nodes having a similar degree connect to each other. A positive coefficient means that nodes sharing the same properties (here, high degree centrality) connect to each other. This last measure thus provides us with an element of understanding of the degree of structural homophily in the network (Crespo et al., 2014).

\section{Results}

\section{Social networks}

As specified, our analysis focuses on videomapping practice in Nantes. Since they live and work in the same city, the actors we interviewed share the same geographical space. Moreover, they have the same techno-creative practice (namely the creation and projection of still and/or moving images using appropriate technology and software) and constitute, de facto, a community of practice (Lave and Wenger, op.cit). The actors share an interest in videomapping and base their practice on usage of this same tool. However, our interviews highlight the fact that the goals and orientations ascribed to their practice are not universal they vary, depending on the actors. Representations of the field, aesthetic values attributed to the productions, and conventions regulating the practice are not shared. (Anand and Watson,

\footnotetext{
${ }^{2}$ Data analysis was conducted with the igraph package of $\mathrm{R}$.
} 
2004). Neither do they belong to the same organizational arrangement (logic of belonging). Actors belong to five distinct sub-groups, which are epistemic communities but do not form a unified community. The first subgroup is made up of mappers from the Nantes School of Architecture, who are former students and teachers. Among them, we find three distinct collectives. The second subgroup is made up of contemporary artists and their technical staff (involved in video, digital and lighting arts), who use this technique in their productions. Some of these people are in a collective and work together regularly. The third subgroup is made of light and video technicians and VJs working in clubs and music venues. They mainly use this technique to enhance festive atmosphere. The fourth group is made up of cultural venue employees having a broad knowledge of cultural activities and practices in the city, but whose interest in videomapping is limited. The fifth subgroup is made up of individuals and collectives who create and take part in cultural events (music, theater) that integrate videomapping. These people collaborate with mappers fairly regularly, and constitute the most diverse category. We can say, then, that the logic of similarity is strong within all five groups, but only potential between them. The actors have a common base of knowledge, skills and interest in videomapping, but values, visions and frames of reference diverge. To some extent, this scattered community is characterized by ambiguity (Sgourev, 2013).

We began by analyzing market relationships between members of the field. This is represented as follows: a link is created if two actors have worked together and/or have a customer/supplier relationship. Market relationships represent $17.6 \%$ of total relations (125 relations). We also noted that the network is assortative $(0.4551551)$, i.e. positive degree correlation of nodes: here, this means that actors have market relationships with others who also have market relationships. In a word, business goes to business. The distribution of the degree of nodes indicates (Figure 2) that the majority have very few market relationships. We also observed, through the distribution of betweenness centrality (Figure 1), that market relations operate through very few nodes. All market relationships are represented in Graph 1.

Figure 1 and Figure 2

Figures 1 and 2 -Actors betweenness distribution and actors degree distribution for market relationships 
The second network represents non-market relationships. Here, a link is created if actors know each other, exchange knowledge or produce innovation together. Non-market relations account for $82.4 \%$ of all trade relations, revealing a higher number of non-market relationships than market relationships. Graph 2 highlights three clusters, each representing sub-components of the mapper network. The degree distribution (Figure 4) indicates a higher number of relationships for each node. Moreover, this network is assortative $(0.2035827)$, though to a lesser extent than the previous one. This means that actors who are already highly connected have relationships with each other, while those who have few relationships are linked to others who also have few relationships. Non-market relations strongly predominate over market relations. The majority have low betweenness centrality (Figure 3). Among identified actors, it is possible for one to have a particularly strong intermediation role, as indicated by their betweenness centrality. We will develop this in the discussion.

Figure 3 and Figure 4

Figures 3 and 4 - Actors betweenness distribution and actors degree distribution for non-market relationships

\section{Graph 2}

Graph 2 - Non-market relationships

\section{Places networks and events networks:}

Next, we traced the network of places attended for market reasons by all sample members. A market relationship is defined here by the fact that an actor has a paid activity in a place (for example, a residence or the dissemination of a production). Thus, when an actor has a market activity in two places, a link is drawn. Graph 3 illustrates this network. Degree centrality indicates that the majority of places have little relationship to one another. This means that not all actors frequent all places (if they did, we would get a complete network). Nevertheless, one place seems to be at the heart of the relationships. This result is confirmed by betweenness centrality. A place would have the role of a strong intermediary for market relations.

Figure 5 and Figure 6 


\section{Graph 3}

Graph 3 - Preferential circulation among places for market relationships

Regarding non-market relationships, the distribution of degree centrality (Figure 6) shows that relationships are distributed more and are less concentrated around a single place. In spite of this, two places in particular seem to be at the heart of the frequentation habits. Moreover, betweenness centrality confirms that few places have a high score (Figure 5). The non-market relationships associated with places are visualized in Graph 4.

Figure 7 and Figure 8

Figures 7 and 8 - Places betweenness distribution and places degree distribution for non-market relationships

\section{Graph 4}

Graph 4 - Preferential circulations among places for market relationships

Regarding events (festivals, fairs, special nights out at a cultural venue), we assume that a market relationship exists where a mapper performs during an event. As with places, a link is drawn when an actor has market activity in two events. Results show a reduced number of events attended by sample members. Degree centrality indicates few opportunities for mappers to show their work at local events, since they attend few events likely to build market relationships (Figure 8). Moreover, the betweenness of events for market relations is low (Figure 7). The events network of market relations is represented by Graph 5.

Figure 9 and Figure 10

Figures 9 and 10 - Events betweenness distribution and events degree distribution for market relationships

\section{Graph 5}

Graph 5 - Preferential circulation among events for market relationships

Non-market relations, on the other hand, are more distributed, revealing that actors attend various events (rather than just one). One seems to be particularly frequented by the members of the sample, as indicated by degree centrality (Figure 9). Betweenness centrality also illustrates that it could offer a context for meeting up (Figure 10). Overall, we can say that both 
the places and the events attended by mappers are heterogeneous. Graph 6 represents the network of events attended for non-market relationships.

Figure 11 and Figure 12

Figures 11 and 12 - Events betweenness distribution and events degree distribution for non-market relationships

Graph 6

Graph 6-Preferential circulation among events for non-market relationships

\section{Discussion}

Analysis of the sample indicates that the actors have compatible heterogeneity, since they are proximate on some points and distant on others. Actors are located in the same city, (geographical proximity) and some even attend the same places (hyper-geographical proximity). Some know each other and form collectives (social proximity and organizational proximity), and have similar knowledge and skills (cognitive proximity). However, social networks are fragmented, and we can see that the subgroups are not very well connected to each other. Some links are observed between the architecture school group and the artists group, though we also note that the sub-component related to events and clubs is disconnected from the main component (Philipps, op.cit). We put forward two explanations for this disconnection: first, cognitive distance would be greater than between the other two sets of the network (architects and artists). Even if all share the same technique, the level of deep technical knowledge is not the same, and the fact that they use less advanced techniques might result in negative evaluation by others. More importantly, the aesthetic codes and the objectives sought through the use of this technique are not the same. Artists use it within the framework of their artistic works, and their discourse is full of artistic references. They situate this in an art world (Becker, 1982) that has pre-formed conventions, and refer to this for their productions. Second, mappers in clubs use mapping to build upon or enhance a festive atmosphere already created by music and lights. The aesthetic vision is therefore not the same, and a kind of symbolic border separates club mappers from the others. For architectural mappers, who have developed a particular perspective in the course of their training, mapping is mainly used to project onto volumes and thus reveal different aspects of the environment. We also believe that architects, because of their training, can play a critical role. The School of Architecture is a place where 
both technical (synthetic) and artistic (symbolic) knowledge are taught. Mastery of these two knowledge bases could facilitate both the other actors' understanding and the interpretation/translation of knowledge.

We note that no integrated videomapping community exists in this territory. As a result, there is also a lack of visibility and legitimacy (Cattani et al, 2017). What does exist is a set of distinct epistemic sub-communities, each with its own representation space and functioning but sharing a technical homophily: actors master the same basic knowledge and share an interest in the videomapping technique. Were they to meet, actors would therefore be able to share knowledge and improve their practice collectively. However, the boundary between the subgroup spaces (which can be linked with institutional proximity) hinder a collective dynamic at whole network level. Spaces are cognitive constructs in which ideas are transferred, translated and articulated: this is the realm of cognitive relations that forms a common vision (Cohendet et al., 2010; Capdevila et al., op.cit). Yet, there is a degree of heterophily between these actors that could be optimal for the development and diffusion of innovations (Rogers, 1983). For the moment, there are no leaders, no actors to guide the practice, and different interpretive frameworks are carried by distinct subgroups. Thus, there is a certain ambiguity as to the aesthetic framework to be developed and the common standards to be adopted. The fragmented subgroups, with their distinct orientations and identities, could be a pre-condition likely to spur knowledge combination and framework reinterpretation (Sgourev, 2013), potentially initiating a distinct cognitive space. Yet this structural fragmentation is also the signature of an emerging knowledge field that has typified the standards battles observed in nascent technological sectors (Suire and Vicente, 2014).

Despite this, we identify several elements that could help bring these actors together in order to gain a level of collective legitimacy and visibility. First, of the actors identified, there is one who, owing to her betweenness centrality, could play a particularly strong intermediation role. She is a former School of Architecture student who moved to Montreal as part of her training. There, she discovered videomapping, met the founder of the Montreal videomapping festival, and later joined the organization team. Following this experience, she returned to Nantes and (along with former student peers) founded the collective that launched the Nantes festival $^{3}$. To achieve this, she had therefore sought out videomappers in Nantes, first through her own friendship network (former students at the architecture school) and then beyond. In this, she relied on an actor working at Stereolux (an important cultural venue in the city) who

\footnotetext{
${ }^{3}$ For the moment, the first edition of Mapp_NTS is postponed due to the Covid-19 pandemic.
} 
has a strong expertise in digital art. This first entry point enabled her to identify other mappers, belonging to the artists subgroup. Since she has been able to bridge two previously disconnected parts of the network, she is now in a structural hole position (Burt, op.cit) and has a broker role. As noted by Foster and Ocejo (2015), the broker position involves a complex process in which an actor may play multiple roles (connecting actors, taking advantage of their position, translating different visions) and where motivation is crucial. In this instance, she has created strategic links with those actors she considers important and whose productions are both relevant and a match for her own vision of videomapping (i.e. those created by architects and artists) - and would probably include these people in the festival program. Crucially, through her previous position in Montreal, she has integrated the field and created global pipelines and imports knowledge, which feed the local buzz (Bathelt et al., 2004; Storper and Venables, 2004). Beyond her structural position in the network, both her vision of the practice and her role as organizer of the festival are crucial to connecting the two main sub-components of the network, through both strong and weak ties.

In this dynamic, places could also play a catalytic role in this context. Of the available places, two are often cited: Stereolux and Lieu Unique. Both places are multi-disciplinary, publicly funded and highly visible. Their programming often relies on artists whose productions interweave the artistic and technological dimensions. Because many actors attend these places for their offer of a dense ("there's often something to see") and varied ("you don't always know what you're going to see") agenda of artistic events, they have high betweenness centrality in the non-market relationships network. These places, then, are open to a wide audience that includes mappers. They are frontier places that allow for inter-community interactions. The case of Stereolux is particularly interesting. It is a formal organization, highly visible and financed by local public institutions. All year round, the venue programs various types of event - live music, exhibitions and performances (about 180 annually). It is also a place of creation, and hosts artist residencies. Having a market relationship with this place can therefore constitute part of the process of local legitimization and recognition, especially for peripheral actors (Grabher, op.cit). It can also open up new opportunities in other places, both locally and further afield. Most mappers belonging to the artists group have already worked there in residency and/or shared their productions with audiences - but the same is not true of members of other subgroups. This place could thus play a crucial role in promoting face-to-face meetings and helping structure a community. Lieu Unique also schedules numerous events - more than 300 each year. Its agenda includes lectures, concerts and exhibitions of contemporary art. 
We also found four other places having high betweenness centrality. A local music venue called the Warehouse is a focal point for events and club mappers. The School of Architecture is a place where actual and former students meet, and the venue for events of the forthcoming videomapping festival. These two venues both create and diffuse productions. Caserne Mellinet is the workspace of a collective of artists, and Ateliers Bonus is where other artists using videomapping have their workspace. These last two are primarily dedicated to creation, as opposed to the exploitation/dissemination of videomapping.

Events (especially the forthcoming videomapping festival) could also play an important role locally. Though it has yet to take place, relationships have already been forged as the program has been put together. As explained above, the organization has sought to combine the artistic and architectural approaches to videomapping, and to this end has created a program featuring members of both subgroups. It will therefore be an event at which encounters can happen, triggering the creation of relationships that do not yet exist. The process of drawing up the program has also been important to the local configuration of this practice. Following the literature focused on field-configuring events (Meyer et al., op.cit; Schüßler et al., op.cit), this process links the macro-dynamics of the field (regarding trends and conventions) with local individual actions (building a collective space and a common aesthetic framework). This is all the more true given that the person initiating the festival has established strong ties with other actors in the field elsewhere; this festival could be a catalyst for the local community (Sgourev, op.cit). Indeed, as stated above, a level of ambiguity exists that is due to a splitting of the community into subgroups associated with different visions of the practice (Sgourev, op.cit). An event with an editorialized program can both orient practice in a particular direction, promoting specific aesthetics, and organize moments of encounter for creators. It also offers an opportunity to meet the public, which can in turn foster recognition and legitimization of the genre (Hsu et al., 2006; Grabher et al., 2008). The current degree of heterophily means that there is no common vision; the festival could actively participate in configuring this practice locally and structuring the community.

Overall, we note preferential circulation and sub-preferential circulation among our sample of places and events, which means that some places/events are attended by one subgroup and not others, for various reasons (geographical proximity of place of work or residence, cultural tastes, etc.). There are also places/events attended by most actors, where people belonging to distinct subgroups are able to meet. In reality, the main venues are those at which interdisciplinary programming intersects with arts and technology (Lieu Unique and Stereolux, 
Scopitone). This provides fertile ground for a community at the intersection of these two sectors, which is a necessary (though not sufficient in and of itself) condition for the development of a common framework. Because they create a favorable context for connecting different social and cognitive realms, these interface places are necessary to innovation at the intersection of art and tech. The maintenance of a certain heterogeneity of places is however also necessary, because this is what allows less visible actors to develop niches and experimentation.

\section{Conclusion}

It is clear that a dynamic of innovation is developing locally around a techno-creative practice that combines synthetic and symbolic knowledge. The literature has highlighted a strong potential for innovation at the intersection of the arts and technology sectors. In the case we studied, it does not yet take the form of an innovation community, since different cognitive spaces are in opposition. The actors we have studied do share proximities, and activation of these could enable the emergence of an innovation community. We identify boundary places and events. Like certain connecting platforms, these can play an important role in structuring a collective innovation dynamic, even serving as intra- and inter-community intermediation mechanisms. They allow a community to gain visibility and legitimacy. Depending on the type of place, they can also promote the creation of standards for creative practice. These places and their articulations in a spatialized network therefore appear necessary to facilitating the structuring of communities of innovation.

\section{Bibliography}

Ambrosino, C., Guillon, V., \& Duvauroux, D. (2016). Genius loci reloaded, The creative renaissance of Nantes and Saint Etienne. In P. Long \& N. D. Morpeth (Eds.), Tourism and the Creative Industries: Theories, policies and practice (p. 116-133). Routledge.

Amin, A., \& Cohendet, P. (2004). Architectures of knowledge: Firms, capabilities, and communities. Oxford University Press.

Anand, N., \& Watson, M. R. (2004). Tournament Rituals in the Evolution of Fields : The Case of the Grammy Awards. The Academy of Management Journal, 47(1), 59-80.

Asheim, B. T., \& Gertler, M. S. (2006). The Geography of Innovation : Regional Innovation Systems. Oxford University Press.

Asheim, B., \& Hansen, H. K. (2009). Knowledge Bases, Talents, and Contexts : On the Usefulness of the Creative Class Approach in Sweden. Economic Geography, 85(4), 425-442. 
Balland, P.A., Suire, R. and Vicente, J. (2013) Structural and Geographical Patterns of Knowledge Networks in Emerging Technological Standards: Evidence from the European GNSS Industry, Economics of Innovation and New Technology, 22(1): 47-72

Balland, P., Jara-Figueroa, C., Petralia, S.G. et al. « Complex economic activities concentrate in large cities", Nature Human Behaviour 4, 248-254

Bathelt, H., Malmberg, A., \& Maskell, P. (2004). Clusters and knowledge: Local buzz, global pipelines and the process of knowledge creation. Progress in Human Geography, 28(1), 31-56.

Bathelt, H., \& Cohendet, P. (2014). The creation of knowledge : Local building, global accessing and economic development - toward an agenda. Journal of Economic Geography, 14(5), 869-882.

Becker, H. S. (1982). Art worlds. University of California Press.

Boix, R., Capone, F., de Propris, L., Lazzeretti, L., and Sanchez, D. 2016. Comparing creative industries in Europe. European Urban and Regional Studies, 23 (4): 935-40.

Boschma, R. (2005). Proximity and Innovation: A Critical Assessment. Regional Studies, 39(1), 61-74.

Boschma, R. (2017). Relatedness as driver of regional diversification : A research agenda. Regional Studies, 51(3), 351-364.

Burt, R. S. (2004). Structural Holes and Good Ideas. American Journal of Sociology, 110(2), 349-399.

Capdevila, I., Cohendet, P., \& Simon, L. (2018). From a local community to a global influence. How elBulli restaurant created a new epistemic movement in the world of haute cuisine. Industry and Innovation, 25(5), 526-549.

Cattani, G., \& Ferriani, S. (2008). A Core/Periphery Perspective on Individual Creative Performance : Social Networks and Cinematic Achievements in the Hollywood Film Industry. Organization Science, 19(6), 824-844.

Gino Cattani, Simone Ferriani, Andrea Lanza (2017), "Deconstructing the Outsider Puzzle: The Legitimation journey of Novelty", Organization Science, 28(6):965-992

Christopherson, S. (2004). The Divergent Worlds of New Media: How Policy Shapes Work in the Creative Economy1. Review of Policy Research, 21(4), 543-558.

Cohendet, P., Grandadam, D., \& Simon, L. (2010). The Anatomy of the Creative City. Industry \& Innovation, 17(1), 91-111.

Content, J., \& Frenken, K. (2016). Related variety and economic development: A literature review. European Planning Studies, 24(12), 2097-2112.

Cowan, R., David, P. A., \& Foray, D. (2000). The explicit economics of knowledge codification and tacitness. Industrial and Corporate Change, 9(2), 211-253.

Crespo, J., Suire, R., \& Vicente, J. (2014). Lock-in or lock-out? How structural properties of knowledge networks affect regional resilience. Journal of Economic Geography, 14(1), 199-219.

Davids, M., \& Frenken, K. (2015). Proximity, knowledge base and the innovation process : The case of Unilever's Becel diet margarine. Papers in Evolutionary Economic Geography, 14(4). Utrecht University.

Davids, M. and Frenken, K. (2018) Proximity, knowledge base and the innovation process - towards an integrated framework, Regional Studies, 52(1), 23-34.

Emin, S., \& Sagot-Duvauroux, D. (2016). L'émergence de dynamiques coopératives : L'exemple d'un réseau d'entreprises créatives co-localisées, Une approche par l'économie des proximités. Géographie Économie Société, 18(4), 525-550.

Florida, R. L. (2002). The rise of the creative class: And how it's transforming work, leisure, community and everyday life. Basic Books.

Frenken, K., Van Oort, F., \& Verburg, T. (2007). Related Variety, Unrelated Variety and Regional Economic Growth. Regional Studies, 41(5), 685-697. 
Foster, P., \& Ocejo, R. E. (2013). The Oxford Handbook of Creative Industries. In C. Jones, M. Lorenzen, \& J. Sapsed (Eds.), Brokerage, Mediation, and Social Networks in the Creative Industries. Oxford University Press.

Gibson, C. (2005). Recording Studios: Relational Spaces of Creativity in the City. Built Environment, 31(3), 192-207.

Grabher, G. (2018). Marginality as strategy: Leveraging peripherality for creativity. Environment and Planning A: Economy and Space, 50(8), 1785-1794.

Grabher, G., Ibert, O., \& Flohr, S. (2008). The Neglected King: The Customer in the New Knowledge Ecology of Innovation. Economic Geography, 84(3), 253-280.

Grandadam, D., Cohendet, P., \& Simon, L. (2013). Places, Spaces and the Dynamics of Creativity: The Video Game Industry in Montreal. Regional Studies, 47(10), 1701-1714.

Granovetter, M. (1985). Economic Action and Social Structure: The Problem of Embeddedness. American Journal of Sociology, 91(3), 481-510.

Haas, P. M. (1992). Introduction: Epistemic Communities and International Policy Coordination. International Organization, 46(1), 1-35.

Hauge, A., \& Hracs, B. J. (2010). See the Sound, Hear the Style : Collaborative Linkages between Indie Musicians and Fashion Designers in Local Scenes. Industry \& Innovation, 17(1), 113-129.

Hsu, G., Hannan, M. T., \& Koçak, Ö. (2009). Multiple Category Memberships in Markets : An Integrative Theory and Two Empirical Tests. American Sociological Review, 74(1), 150-169.

Ingstrup, M. B., \& Menzel, M.-P. (2019). The emergence of relatedness between industries: The example of offshore oil and gas and offshore wind energy in Esbjerg, Denmark. Papers in Evolutionary Economic Geography, 19(29). Utrecht University.

Janssen, M. J., \& Frenken, K. (2019). Cross-specialisation policy : Rationales and options for linking unrelated industries. Cambridge Journal of Regions, Economy and Society, 12(2), 195-212.

Jones, C., Hesterly, W. S., \& Borgatti, S. P. (1997). A General Theory of Network Governance: Exchange Conditions and Social Mechanisms. The Academy of Management Review, 22(4), 911-945.

Kloosterman, R. C. (2014). Cultural Amenities: Large and Small, Mainstream and Niche-A Conceptual Framework for Cultural Planning in an Age of Austerity. European Planning Studies, 22(12), 2510-2525.

Kloosterman, R. C, \& Brandellero, A. (2016). « All these places have their moments » : Exploring the Micro-Geography of Music Scenes: The Indica Gallery and the Chelsea Hotel. $M / C$ Journal, 19(3).

Landry, C., \& Bianchini, F. (1995). The Creative City. Demos.

Lavanga, M. (2018). The role of Pitti Uomo trade fair in the menswear fashion industry. In R. Blaszczyk \& B. Wubs (Éds.), The Fashion Forecasters : A Hidden History of Color and Trend Prediction (p. 191-209).

Lave, J., \& Wenger, E. (1991). Situated learning : Legitimate peripheral participation. Cambridge University Press.

Lingo, E. L., \& O’Mahony, S. (2010). Nexus Work : Brokerage on Creative Projects. Administrative Science Quarterly, 55(1), 47-81.

Maskell, P., Bathelt, H., \& Malmberg, A. (2006). Building global knowledge pipelines : The role of temporary clusters. European Planning Studies, 14(8), 997-1013.

Meyer, A. D., Gaba, V., \& Colwell, K. A. (2005). Organizing Far from Equilibrium : Nonlinear Change in Organizational Fields. Organization Science, 16(5), 456-473.

Mills, A. J., Durepos, G., \& Wiebe, E. (Éds.). (2010). Encyclopedia of case study research. SAGE Publications.

Meyer, A. D., Gaba, V., \& Colwell, K. A. (2005). Organizing Far from Equilibrium : Nonlinear Change in Organizational Fields. Organization Science, 16(5), 456-473. 
Nooteboom, B., Van Haverbeke, W., Duysters, G., Gilsing, V., \& van den Oord, A. (2007). Optimal cognitive distance and absorptive capacity. Research Policy, 36(7), 1016-1034.

Oldenburg, R. (1989). The Great Good Place: Cafes, Coffee Shops, Bookstores, Bars, Hair Salons, and Other Hangouts at the Heart of a Community. Paragon House. 338 p.

Perry-Smith, J. E., \& Shalley, C. E. (2003). The Social Side of Creativity: A Static and Dynamic Social Network Perspective. The Academy of Management Review, 28(1), 89-106.

Phillips, D. J. (2011). Jazz and the Disconnected: City Structural Disconnectedness and the Emergence of a Jazz Canon, 1897-1933. American Journal of Sociology, 117(2), 420-483.

Punstein, A. M., \& Glückler, J. (2020). In the mood for learning? How the thought collectives of designers and engineers co-create innovations. Journal of Economic Geography, 20(2), 543-570.

Rallet, A., \& Torre, A. (2004). Proximité et localisation. Économie rurale, 280(1), 25-41.

Rantisi, N. M. (2014). Exploring the role of industry intermediaries in the construction of 'Local Pipelines': The case of the Montreal Fur Garment Cluster and the rise of Fur-Fashion connections. Journal of Economic Geography, 14(5), 955-971.

Rantisi, N. M., \& Leslie, D. (2010). Materiality and Creative Production: The Case of the Mile End Neighborhood in Montréal. Environment and Planning A: Economy and Space, 42(12), 2824-2841.

Rodríguez-Pose, A., \& Lee, N. (2020). Hipsters vs. geeks? Creative workers, STEM and innovation in US cities. Cities, 100.

Rogers, E. M. (1983). Diffusion of innovations. Free Press.

Sarazin, B., Cohendet, P., \& Simon, L. (Eds.). (2017). Les communautés d'innovation: De la liberté créatrice à l'innovation organisée. Éditions EMS, Management \& Société.

Schieb-Bienfait, N., Saives, A.-L., \& Charles-Pauvers, B. (2018). Urban Creative and Cultural Entrepreneurs: A Closer Look at Cultural Quarters and the Creative Clustering Process in Nantes (France). In E. Innerhofer, H. Pechlaner, \& E. Borin (Eds.), Entrepreneurship in Culture and Creative Industries: Perspectives from Companies and Regions (p. 341-353). Springer International Publishing.

Schüßler, E., Grabher, G., \& Müller-Seitz, G. (2015). Field-Configuring Events : Arenas for Innovation and Learning? Industry and Innovation, 22(3), 165-172.

Scott, A. J. (2014). Beyond the Creative City: Cognitive-Cultural Capitalism and the New Urbanism. Regional Studies, 48(4), 565-578.

Sedita, S. R., de Noni, I., and Pilotti, L. 2016. Out of the crisis: An empirical investigation of placespecific determinants of economic resilience. European Planning Studies, 25(2): 155-80.

Sgourev, S. V. (2013). How Paris Gave Rise to Cubism (and Picasso): Ambiguity and Fragmentation in Radical Innovation. Organization Science, 24(6), 1601-1617.

Sgourev, S. V. (2015). Brokerage as Catalysis: How Diaghilev's Ballets Russes Escalated Modernism. Organization Studies, 36(3), 343-361.

Storper, M., \& Venables, A. J. (2004). Buzz : Face-to-face contact and the urban economy. Journal of Economic Geography, 4(4), 351-370.

Suire, R. (2019). Innovating by bricolage : How do firms diversify through knowledge interactions with FabLabs? Regional Studies, 53(7)1-12.

Suire, R., \& Vicente, J. (2015). Récents enseignements de la théorie des réseaux en faveur de la politique et du management des clusters. Revue d'économie industrielle, 152, 91-119.

Suire, R., \& Vicente, J. (2014). Clusters for life or life cycles of clusters : In search of the critical factors of clusters' resilience. Entrepreneurship \& Regional Development, 26(1-2), 142-164.

Torre, A. (2008). On the Role Played by Temporary Geographical Proximity in Knowledge Transmission. Regional Studies, 42(6), 869-889.

Uzzi, B., \& Spiro, J. (2005). Collaboration and Creativity: The Small World Problem. American Journal of Sociology, 111(2), 447-504. 